\title{
On the origin of both a recent and submerged tombolo on Prvić Island in the Kvarner area (Adriatic Sea, Croatia)
}

\author{
Čedomir Benac ${ }^{1}$, Neven Bočić ${ }^{2}$ and Igor Ružić ${ }^{1}$ \\ 1 University of Rijeka, Faculty of Civil Engineering, Department of Hydrotechnics and Geotechnics, Radmile Matejčić 3, 51000 Rijeka, Croatia; \\ (cbenac@gradri.uniri.hr; iruzic@uniri.hr) \\ 2 University of Zagreb, Faculty of Science, Department of Geography, Marulićev trg 19/Il, 10000 Zagreb, Croatia; (nbocic@geog.pmf.hr)
}

doi: $10.4154 / g c .2019 .14$

Article history:

Manuscript received September 20, 2018

Revised manuscript accepted June 21, 2019

Available online October 31, 2019

\begin{abstract}
This paper analyzes the origins of two tombolos (one recent and another fossil/submerged) on the southwestern coast of Prvić Island, which is located in the Kvarner area in the northeastern part of the Adriatic Sea.

A recent tombolo on Cape Pipa was formed by the erosion of Quaternary deposits and Palaeogene siliciclastic rocks. The submerged tombolo is much bigger, clearly visible on the sea bed toward the southwest. The conditions for forming a submerged and recent tombolo have occurred during a slow rise and then stagnation of sea level of the Adriatic Sea in the Holocene. The sea flooded the fossil tombolo probably in the final part of a period of rapid sea-level rise at the beginning of the Holocene when a large proportion of the Quaternary sediments were eroded. Waves from the northwest (tramuntana) and southeast (jugo) refract and diffract around the tombolo. The nourishment of the beach body happens permanently on both sides of the cape. Accumulated sediments are protected by resistant rocky blocks of breccia on the peak of Cape Pipa, acting as a natural tombolo. Due to the fact that wave directions are perpendicular to the beach coastline, they do not generate longshore currents that would erode sediment in beach bodies around Cape Pipa. Therefore, the recent tombolo is probably stable in the present climatic and oceanographic conditions in the Kvarner area.
\end{abstract}

Keywords: tombolo, marine erosion, coastal geomorphology, sea-level rise, Holocene the most common but there are also tombolo pairs and triplets (GOSSEAUME, 1973; MARRINER et al., 2008; CEYLAN, 2012). The preconditions for tombolo formation are: (i) high sediment supply, (ii) a physical barrier against the swell and (iii) coastal processes conducive to the development of a sand bank, i.e., bidirectional currents converging towards this physical barrier (DAVIES, 1980, according to MARRINER et al., 2008). Geomorphological forms like tombolos are rare on the Croatian coast of the Adriatic Sea and have not been studied in the scientific literature so far. This is the first known scientific research of the morphogenesis of recent and submerged tombolos at nearby locations.

\section{STUDY AREA}

Prvić Island is elongated in the NW-SE direction. The surface of the island is $12.76 \mathrm{~km}^{2}$, maximum length is $7.84 \mathrm{~km}$, maximum width is $2.6 \mathrm{~km}$ and the total length of the coast is $23.12 \mathrm{~km}$ (DUPLANČIĆ-LEDER et al., 2004). The highest peak of the island is $356 \mathrm{~m}$ above mean sea level (m.s.l), (Fig. 1C).

This island is mostly formed of carbonate rocks consisting of Upper Cretaceous limestone and dolomitic limestone, Palaeogene foraminiferal limestone, and partially of Palaeogene siliciclastic rocks i.e. marls and flysch (MAMUŽIĆ et al., 1969; BENAC et al., 2013). The bare karstic plateau in the central area of the island has an elevation of $>300 \mathrm{~m}$ above m.s.l. (Fig. 1B, C).

The northeastern slopes between cape Stražica (NW) and Cape Šilo (SE) are mostly very steep, with an average inclination $>70^{\circ}$, and many vertical scarps are located above the shore. The carbonate rock mass is partially covered by active talus. Submarine slopes are also very steep, resulting in the $50 \mathrm{~m}$ isobath being
Tombolos length varies from few tens of metres behind small obstacles, up to more than ten kilometers. Single tombolos are 

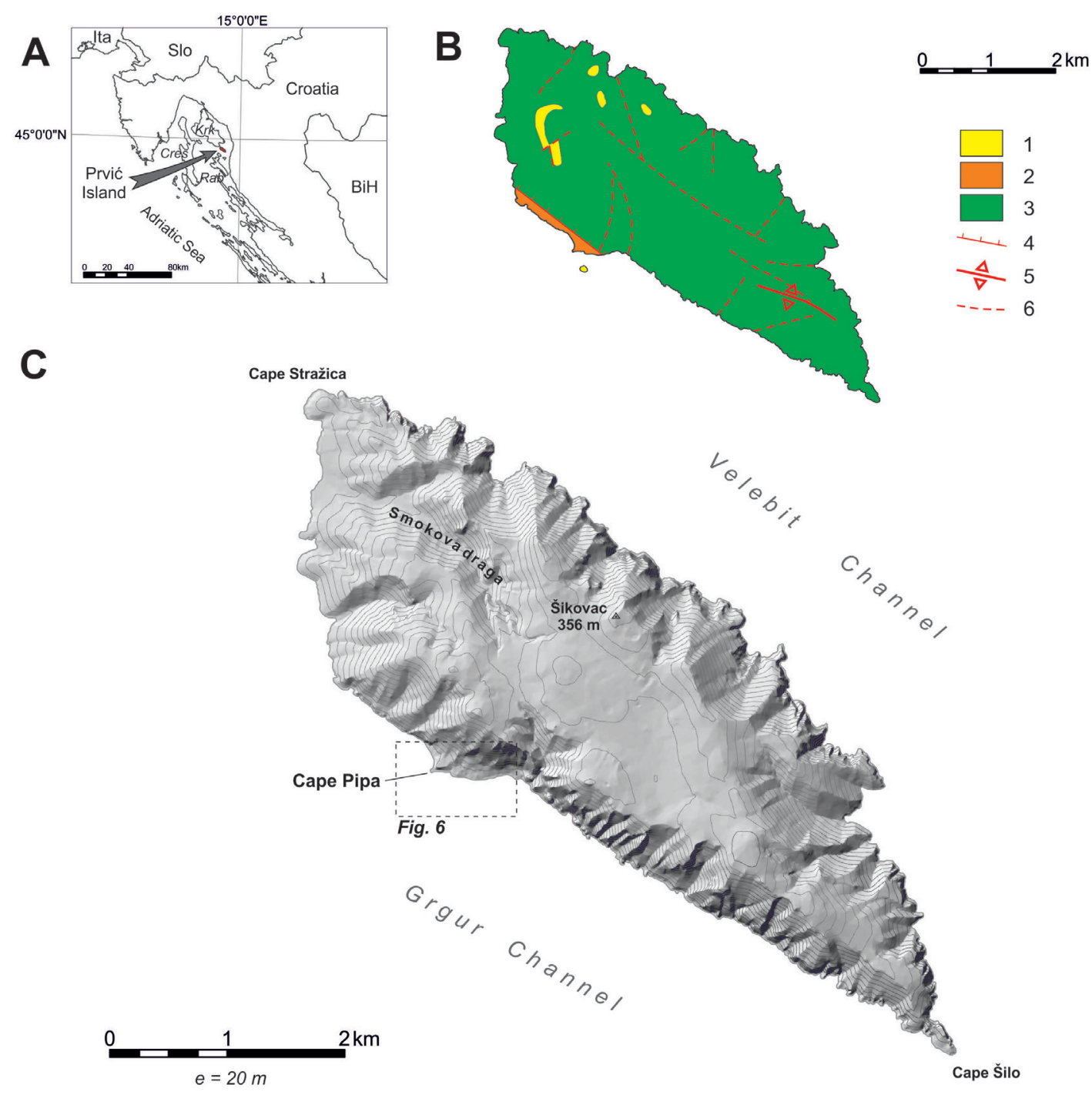

Figure 1. A-Location map; B-Simplified geological map (according to MAMUŽı́ et al., 1969): 1-Neogene limestone breccia, 2-Palaeogene foraminiferal limestone and flysch, 3-Upper Cretaceous limestone and dolomitic limestone, 4-reverse fault, 5-anticline axis, 6-proposed fault; C-basic relief characteristics of Prvić Island.

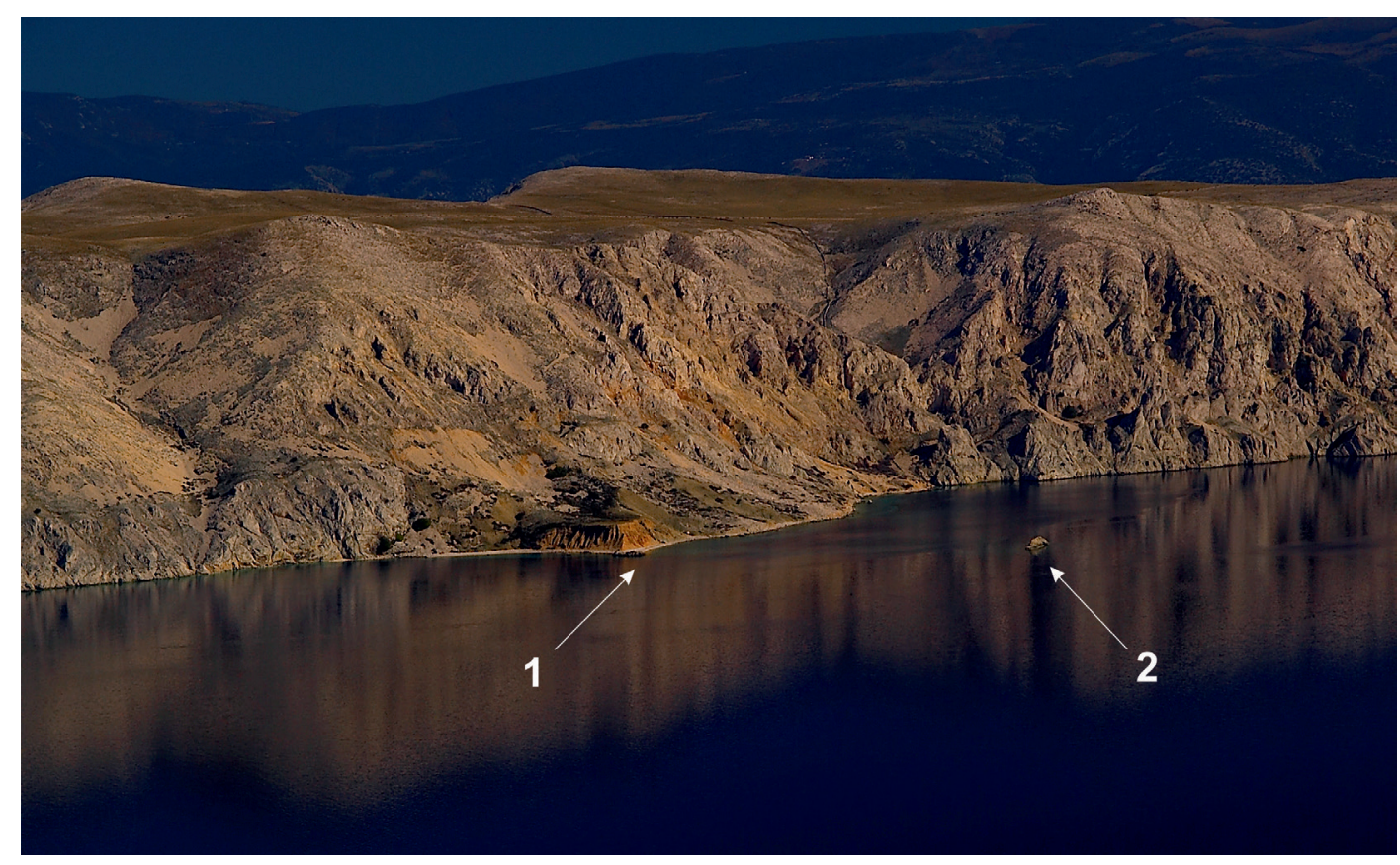

Figure 2. The southwestern coast of Prvić Island (photo: Ž. Gržančić): 1 - Cape Pipa, 2 - the Njivice Rock. 


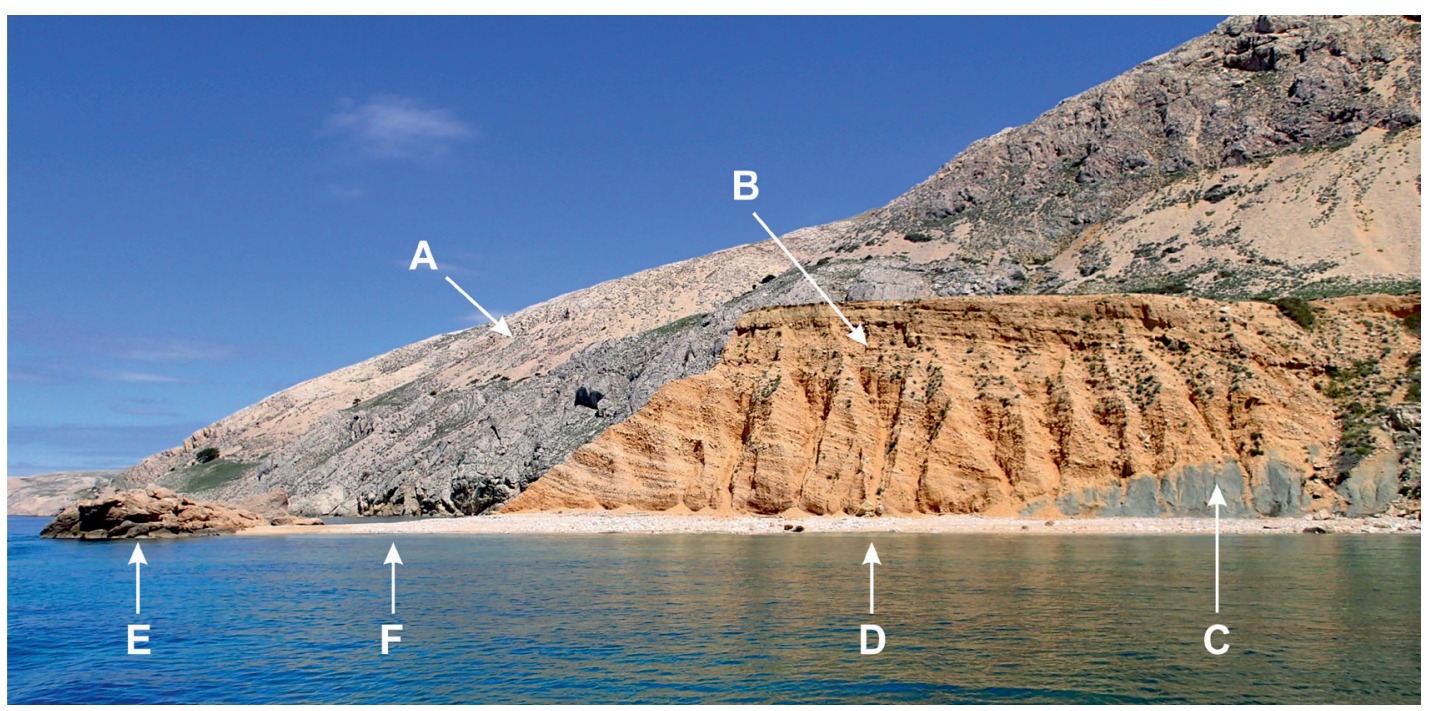

Figure 3. Cape Pipa (photo: Č. Benac): A) carbonate rock mass, B) Quaternary sediments, C) Palaeogene flysch, D) gravely beach, E) collapsed blocks of limestone breccia - an obstacle, F) tombolo.

mostly $<100 \mathrm{~m}$ from the coastline. The slopes are more gently inclined in the western part of the island. A dry karstic valley, the Smokova draga is a dominant exogenous geomorphological form (Fig. 1C).

Cape Pipa is located in the central part of the southwestern coast of Prvić Island where the coastal relief and geologic fabric are very different in relation to other coastal parts of this island. Steep or vertical upper parts of the slopes are formed of carbonate rocks, and the tectonic fabric is complex and not well known. The contact between these carbonate and siliciclastic rocks in the lower part of the slope is a NW-SE trending reverse fault (MAMUŽIĆ et al., 1969), (Fig. 1B).

Large blocks of limestone breccia form Cape Pipa itself and sandy and gravely beaches have formed along both sides of the cape (Fig. 2). The sea bed is at a shallow depth around this cape.

Approximately 340 metres SSE from Cape Pipa lies the Njivice Rock (Fig. 2). It is a small rock with a length of about $50 \mathrm{~m}$ striking W-E. Its largest width is about $12 \mathrm{~m}$, its height is $4 \mathrm{~m}$ and its surface is approximately $500 \mathrm{~m}^{2}$. The Njivice Rock is also built of carbonate breccia, probably of Palaeogene age. The investigated part of Prvić Island is exposed to waves from both the southeast and the northwest which are relatively low compared to waves in the open sea due to their small fetch (see below).

\section{METHODS}

Three different methods were used in this study. In the preparatory phase, various maps were used to provide information on the geomorphological phenomena of the area: topographic map 1: 25,000, Croatian base map (1:5000) and Digital orthophoto $\mathrm{map}^{1}$. According to information from the visual interpretations of these maps, we found this specific location and recognized active and submerged tombolos at nearby locations. Further, we used orthophoto map as a base for the field investigation.

The second method was field investigation. The main purpose of the field work was to collect data on landforms and their relationship with the geological structure of the terrain in the wider area of Cape Pipa. Data were obtained by aerial photogra- phy from an aircraft, geological and geomorphological mapping, and reconnaissance of the underwater part of the exploration area using scuba diving equipment. For geomorphological mapping, a customized methodology was used according to GAMS et al. (1985) and PAVLOPOULOS et al. (2009). This methodology is based on the morphogenetic determination of observed geomorphological processes, forms and conditions which are related to the morphogenesis of tombolos. The geomorphological mapping involved recognizing, locating and drawing on the map the main forms and processes of the coastal and slope morphogenetic type of relief with the main purpose of determining their spatial relationships.

In order to determine the influence of waves on the formation of the tombolos, numerical modeling was used. Numerical simulation was performed using the Simulating Waves Nearshore (SWAN) numeric model, which is the third generation model for application in coastal areas, based on Euler's equilibrium equation of spectral waveform (BOOIJ et al., 1999). A JONSWAP wave spectrum with parameter $\gamma=3.3$ was used. Numerical simulation of waves was carried out in the wider area of the Grgur Channel for waves of northwestern (generated by tramuntana wind) and southeastern directions (generated by jugo). The numerical simulation was done for the 50 -year return period and for mean sea level. Relevant wind strengths for numerical simulation (southeastern direction: $27.4 \mathrm{~m} / \mathrm{s}$, northwestern direction: 22.2 $\mathrm{m} / \mathrm{s}$ ) were taken from the wind climate study of the nearby Vinodol Channel' ${ }^{2}$.

Based on the data collected from the maps and field work, geomorphological analysis and synthesis were carried out, focusing on the geological and oceanographic conditions, forms and processes that created the recent features of the relief on Cape Pipa.

\section{RESULTS}

Cape Pipa is formed by sea erosion of the Palaeogene siliciclastic rocks (marls and flysch) which are partially covered with younger cohesive sediments, probably of Quaternary age (Fig. 3). This

\footnotetext{
${ }^{1}$ https://geoportal.dgu.hr/Geoportal, State Geodetic Administration, Zagreb

${ }^{2}$ Croatian Meteorological and Hydrological Service (2006): Wind climate for the area at Dubračina mouth in Crikvenica. Zagreb
} 
¿ Quaternary sediment body has a form of an irregular triangle with a base length of around $50 \mathrm{~m}$. The height of this Quaternary deposit is 10 to $12 \mathrm{~m}$, and outcrops of flysch bedrock are partially visible on its southeastern side. The stratification of the Quaternary sediment body is clearly visible and bedding planes have a gentle inclination opposite to the coastal slope. According to preliminary field observations, silty sand prevails in this sediment body. Some layers contain angular fragments and blocks that originate from the carbonate rock mass. The coastal cliff is formed on both sides of this sediment body.

Cape vertex itself is formed on collapsed blocks of talus breccia and provides an obstacle to wave motion (Fig. 3). Behind this obstacle is the accumulation of beach sediments that connect Cape Vertex with the coast. Cape Pipa, according to geomorphological classification (WARD, 2004), can be characterized as a tombolo. Grains of gravel with an average diameter between 2 and $6 \mathrm{~cm}$ prevail in the beach body. Coarse sand and subangular pebble grains are partially visible. A much bigger triangular tombolo form is clearly visible on the sea bed southwest of Cape Pipa. The edges of this form are built of submerged beach sediments. So, we can consider it as a palaeo-coastline, approximately $300 \mathrm{~m}$ long. Concave traces of ancient coast are clearly visible on the western side and less noticeable on the southeastern side (Fig. 4). This submerged tombolo form was formed behind another obstacle. The Njivice Rock is built of carbonate breccia, probably

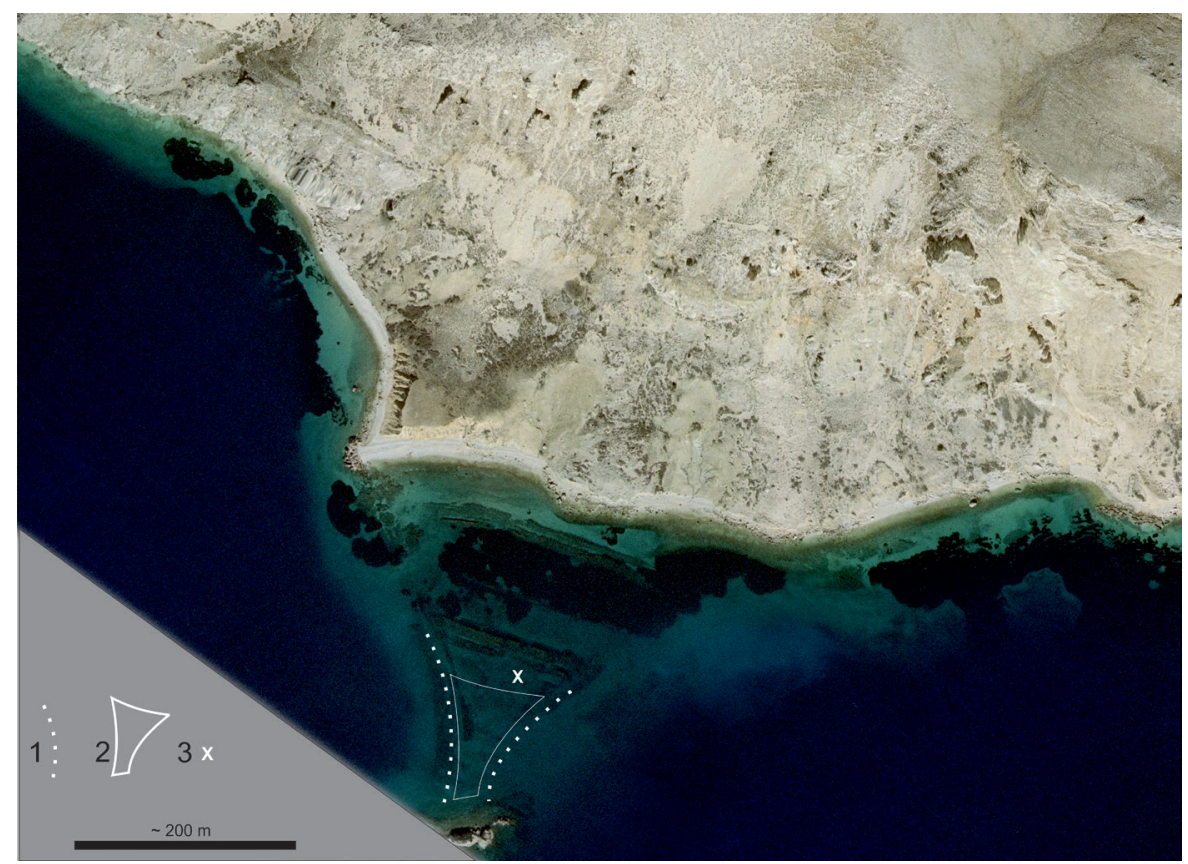

Figure 4. Ortho-photo image of Cape Pipa and the submerged tombolo (dark spots are meadows of Posidonia oceanica) 1-submerged beaches, 2-supposed area of submerged tombolo, 3-location of Fig. 5.

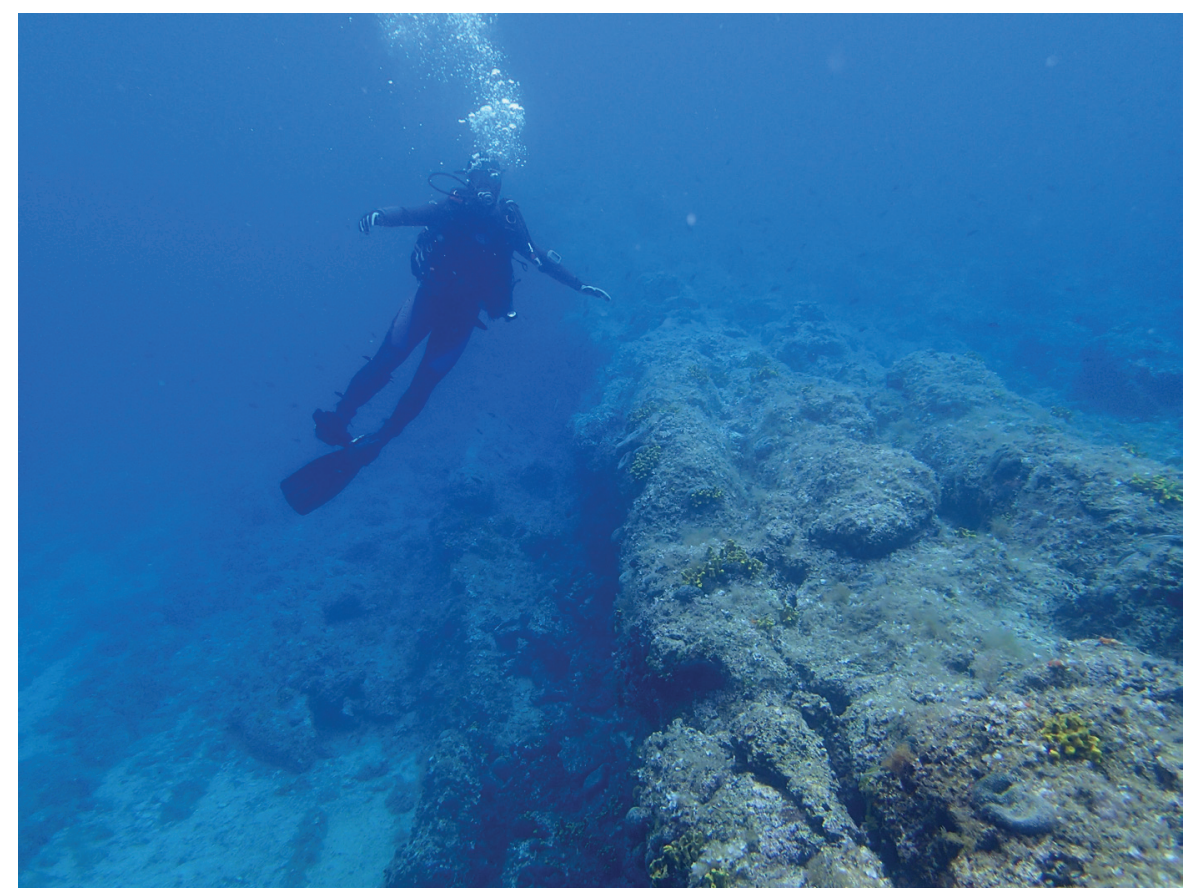

Figure 5. Outcrops of subvertical layers (photo: Č. Benac) (precise location is visible in Fig. 4). 


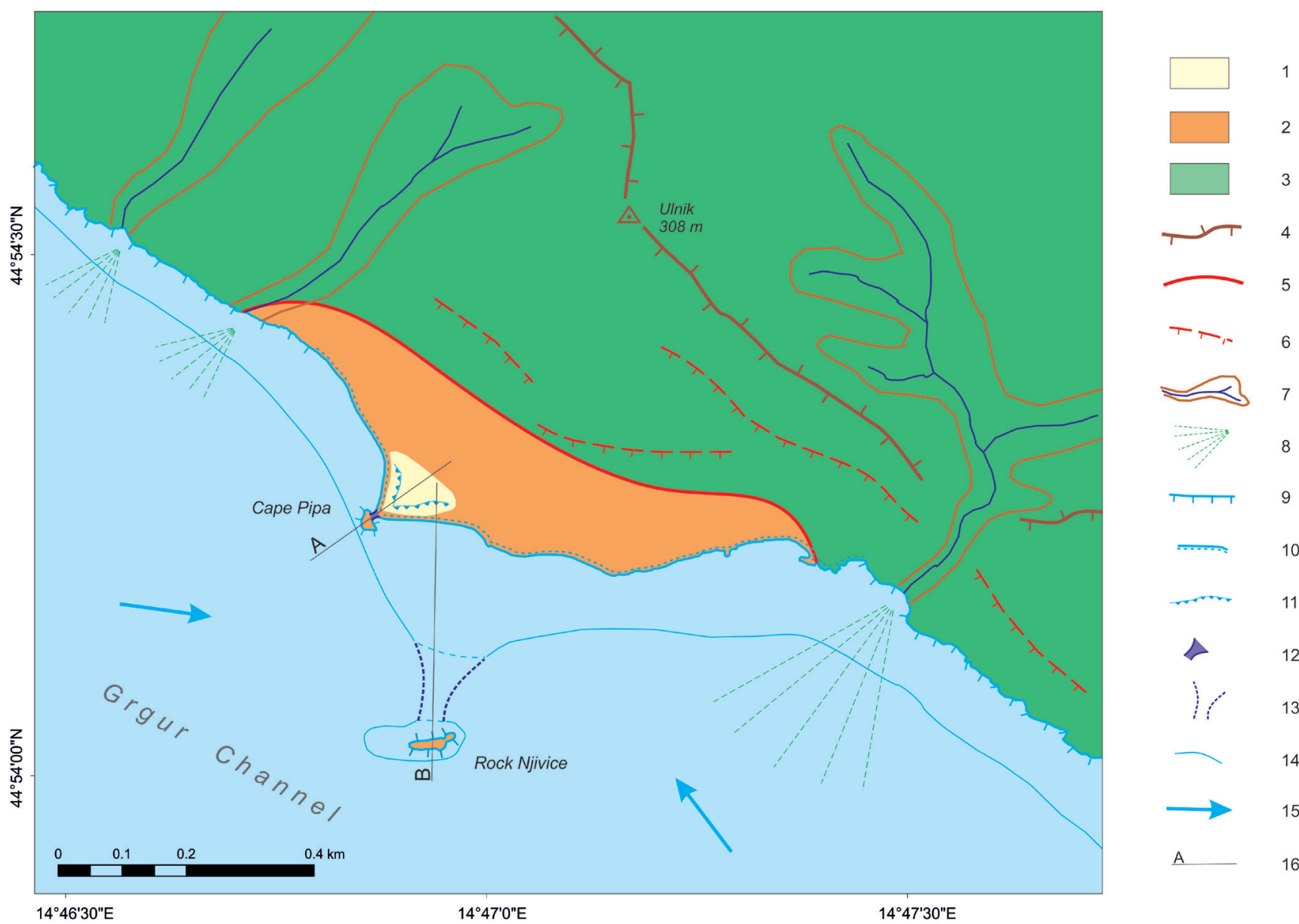

Figure 6. A geomorphological map of Cape Pipa and the surrounding area. 1-Quaternary sediments, 2-Palaeogene flysch mostly covered by slope deposits, 3-carbonate rock mass (Upper Cretaceous limestone and dolomitic limestone and Palaeogene foraminiferal limestone), 4-main ridges, 5-reverse fault, 6-fault escarpment, 7-gully, 8-assumed submerged prolluvium fan, 9-recent shoreline in carbonate rock mass, 10-beaches (coarse sand and gravel), 11-recent cliff, 12-recent tombolo, 13-submerged tombolo, 14-assumed position of the shoreline at the time of submerged tombolo genesis, 15-direction of major waves, 16-position of geological cross-sections (see Fig. 7).
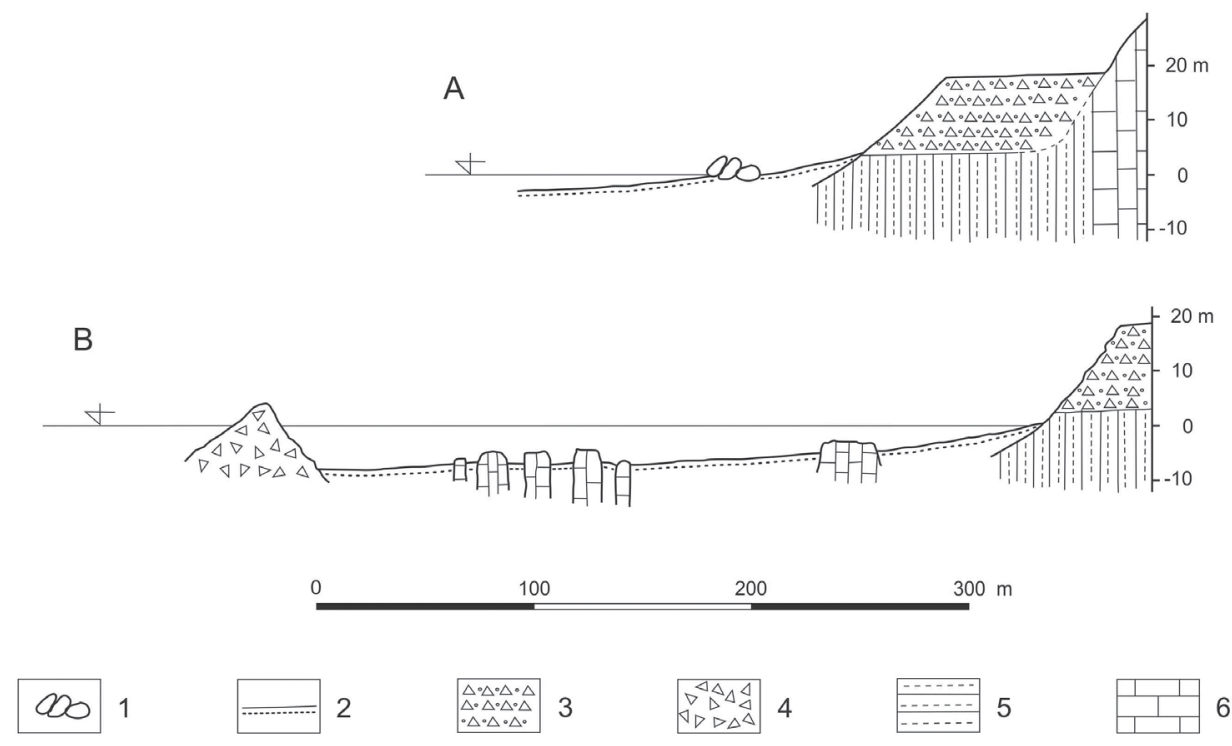

Figure 7. Geological cross-sections of the submerged and recent tombolos. 1-recent collapsed blocks of breccia, 2-beach sediments (coarse sand and gravel), 3-Quaternary sediments (carbonate blocks, fragments and silty sand), 4-Palaeogene (?) limestone breccia, 5-Palaeogene flysch, 6-more resistant layers in Palaeogene flysch.

of Palaeogene age. This submerged tombolo lies at an approximate depth of 10 metres below the recent sea level.

Unusual dark parallel lines are clearly visible on the orthophoto image where these submerged outcrops look like artifi- cially built walls (Fig. 4). Exploration using scuba-diving equipment has revealed that they are outcrops of vertical layers of rocks (Fig. 5). At first glance, they seem to be carbonate members of a flysch rock mass (calc-arenite and calc-rudite). 

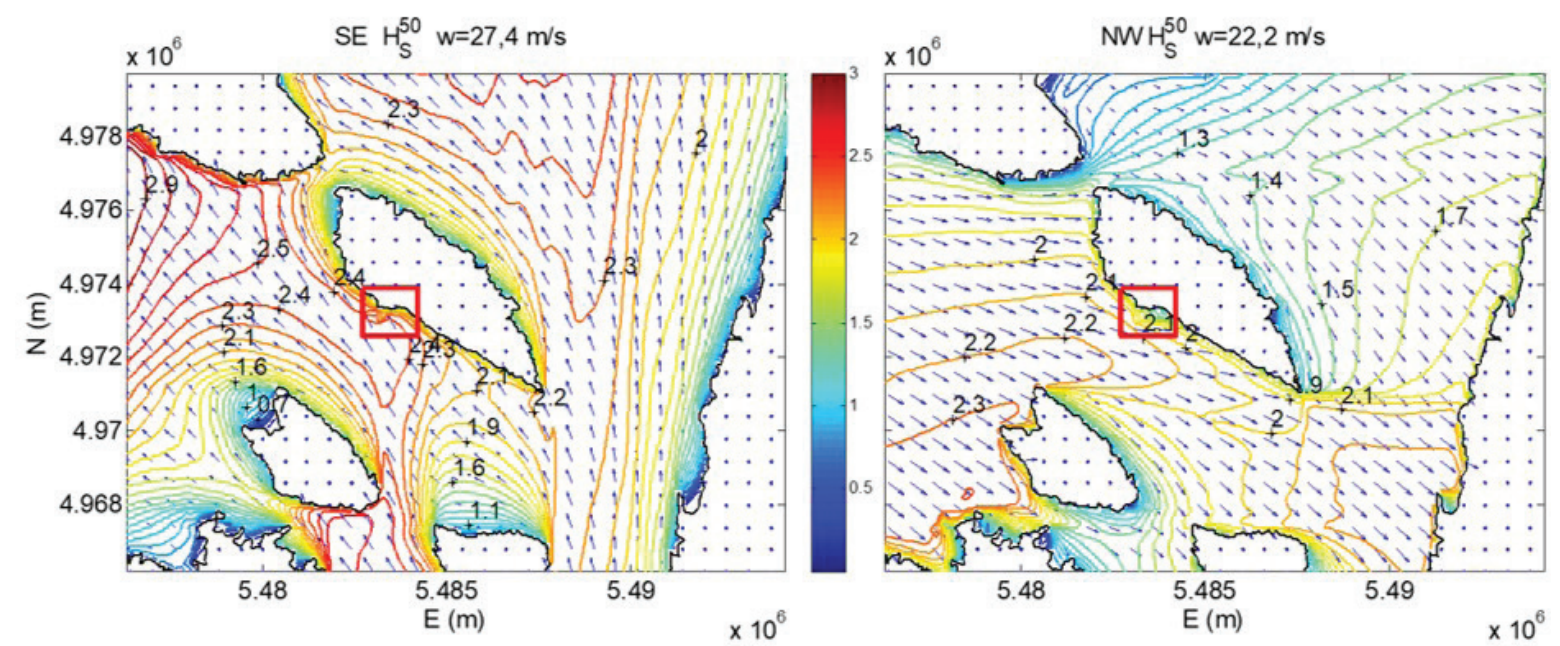

Figure 8. Significant wave height (in metres) and the main wave direction of 50 - year return period in the Grgur Channel.

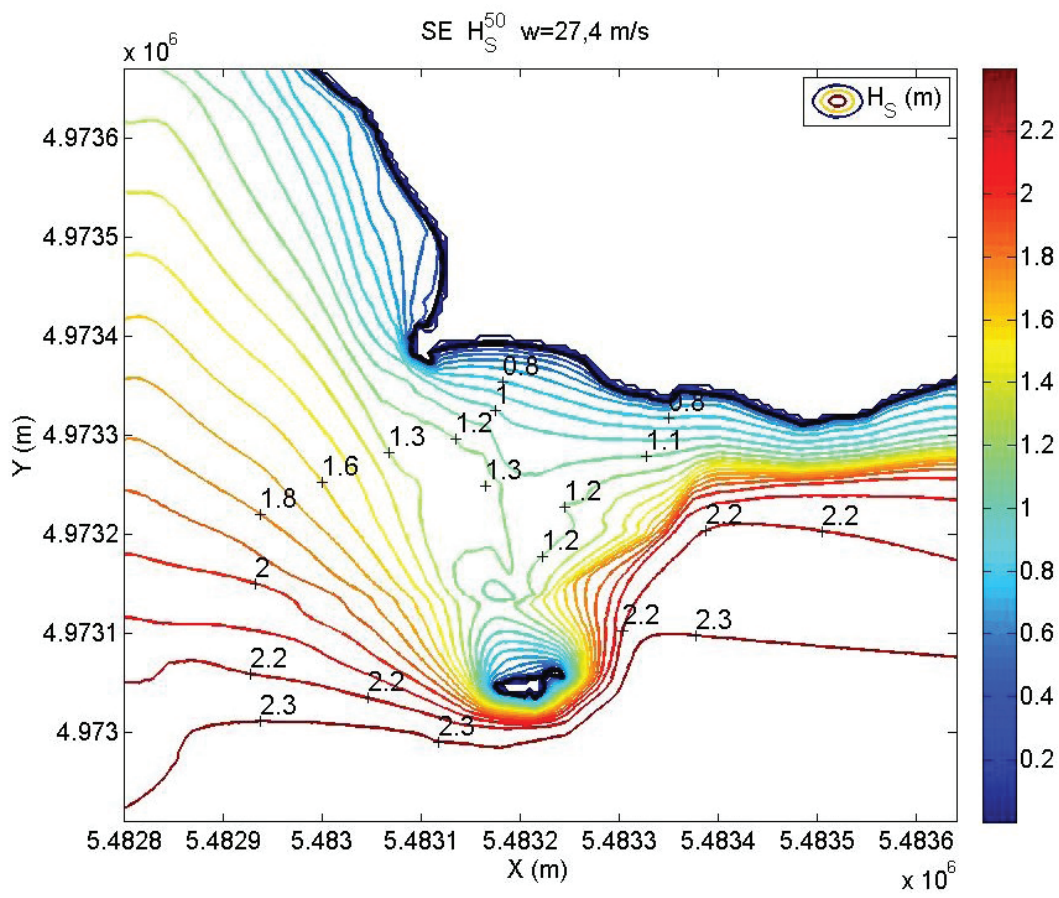

Figure 9. Significant wave heights from southwest wave directions for a 50 - year return period (in metres) at Cape Pipa and the Njivice Rock.

Geomorphological and geological conditions in the surrounding area are shown in Figures 6. and 7. The recent coastline in the area around the tombolos was formed in Palaeogene siliciclastic rocks and limestone. A little further away, the coast was formed in Cretaceous carbonate rocks. Palaeogene (siliciclastic and carbonate) rocks are present only at lower elevations whereas Cretaceous carbonate rocks are more distant from the beach, on higher elevations with steep slopes.

The inland of the Prvić Island is predominantly formed of Cretaceous carbonate rocks with a few deep gullies. These carbonate rocks are karstified, but on the steep slopes intensive linear erosion is also present. According to the shape of the contours and isobaths on topographic maps, we can hypothesize that sediment eroded from the gullies formed some prolluvium fans, which are now submerged (Fig. 6).

Geological cross-sections indicate several favourable factors that enabled the development of the investigated tombolos (Fig. 7). In addition to the above mention obstacles of different geo- logical origins, the source of beach accumulation material is important. These are most likely the Quaternary sediment body from Cape Pipa and probably Palaeogene flysch (Fig. 6). It is possible that a source of material for the submerged tombolo was the supposed submerged prolluvium fans, but probably in small proportions. The vertical position of the more resistant layers in flysch rock mass (Figs. 5, 7) was also likely to have helped protection against marine erosion of these sediments.

The southeastern and northwestern wind directions generate the highest waves in the Grgur Channel. Figure 8 shows significant wave height and wave direction simulations using the SWAN model (BOOIJ et al., 1999), which assumes a uniform wind distribution. According to model results, wind waves coming from the southeast $\left(\mathrm{H}_{\mathrm{S}}{ }^{50}=2.40 \mathrm{~m}\right)$ are higher than ones coming from the northwest $\left(\mathrm{H}_{\mathrm{S}}{ }^{50}=2.00 \mathrm{~m}\right)$ in the Grgur Channel. The recent tombolo and the adjacent coast of Prvić Island are protected from waves from the southeast direction. Waves from southeastern directions break on the Rock of Njivice, and significant shoaling 

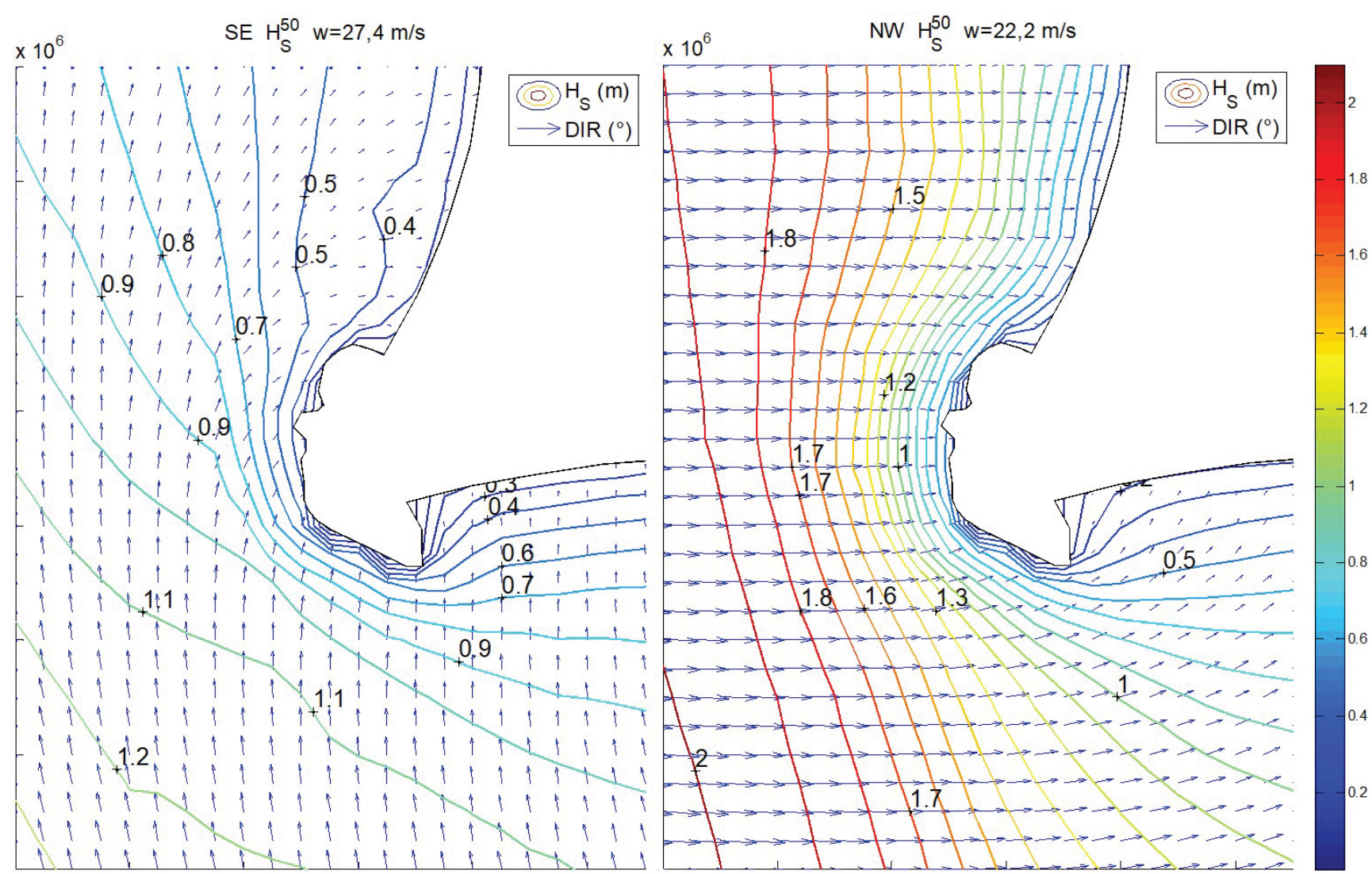

Figure 10. Significant wave heights (in metres) from the main wave direction for 50 - year return period at Cape Pipa.

occurs at the submerged tombolo (Figs. 6, 9, 10). Wind waves from northwestern directions have higher significant wave heights of the same return period than waves from southeastern directions on Cape Pipa (Fig. 10).

The effects of wave diffraction and shoaling are clearly manifested around Cape Pipa. A majority of the incoming wave's energy dissipates on Cape Pipa and the surrounding seabed. Behind this cape, there is a shadow zone with low wave energy which provides tombolo stability.

\section{DISCUSSION}

Geomorphologic forms like a tombolo are rare along the Croatian coast of the Adriatic Sea, due to the prevalence of relative resistant carbonate rocks in which processes of mechanical marine erosion are less well expressed (PIKELJ \& JURAČIĆ, 2013). The same situation occurs in the Kvarner area, where a very slow process of bioerosion prevails, while marine erosion is more strongly expressed in the less resistant siliciclastic rocks and Quaternary deposits (JURAČIĆ et al., 2009). The origin of the described deposits at Cape Pipa had not been investigated in detail. According to MARJANAC (2012) these deposits (Fig. 3) can be considered as the remains of the glacial terrace.

The question arises as to why recent and submerged tombolos were formed in nearby locations? The cause may be three geomorphological factors: (1) a specific geological fabric on the southwestern side of Prvić Island, (2) favourable oceanographic conditions in the Grgur Channel and (3) the sea level change during the Holocene.

Exogenous slope geomorphological processes are very intense on the southwestern coast of Prvić Island, especially where active talus formation and rock sliding are visible (Fig. 2). The erosion of the Quaternary sediment body on Cape Pipa is permanent. Sheet wash and rilling types of erosion caused by surface water are visible and consequently, additional feeding of the beach sediment body is active on both sides of the cape (Figs. 3, 6).

Behind barriers, a complicated mechanism of waves, currents, sediment transport, and morphology occurs. At Cape Pipa, wave energy will be reflected dissipated and transmitted by overtopping, waves also diffract around the tombolo (Fig. 10). As a result, they generate longshore currents of opposite directions and support erosion or accumulation of sediment in beach bodies around Cape Pipa.

Accumulated sediments are then protected by a resistant block of breccia on the peak of Cape Pipa, creating a natural tombolo (Fig. 11), as wave directions on the windward side are perpendicular to the beach coastline, and sediment longshore transport on the tombolo is minimal (Fig. 10). Wave setup in the lee is a combination of diffraction, transmission and partly refraction. The wave direction and energy behind Cape Pipa seem favourable for sediment accumulation and retention due to reduced erosion caused by longshore currents.

The recent tombolo is in a state of equilibrium in the present climatic and oceanographic conditions in the Kvarner area (PENZAR et al., 2001). Stagnation of sea level occurred in the last 7000 years, after the rapid Late Pleistocene-Holocene rise in the Adriatic Sea (LAMBECK et al., 2004; SURIĆ, 2009; BENJAMIN et al., 2017). Erosion of an ancient large sediment body has been intensive during this period. Namely, the described Quaternary sediment body has features of a cohesive soil. Therefore, mechanical weathering and erosion are intensive and permanent. This sediment body has lower resistance to destructive wave attack in relation to the carbonate rocks. The coarse-grained sedi- 


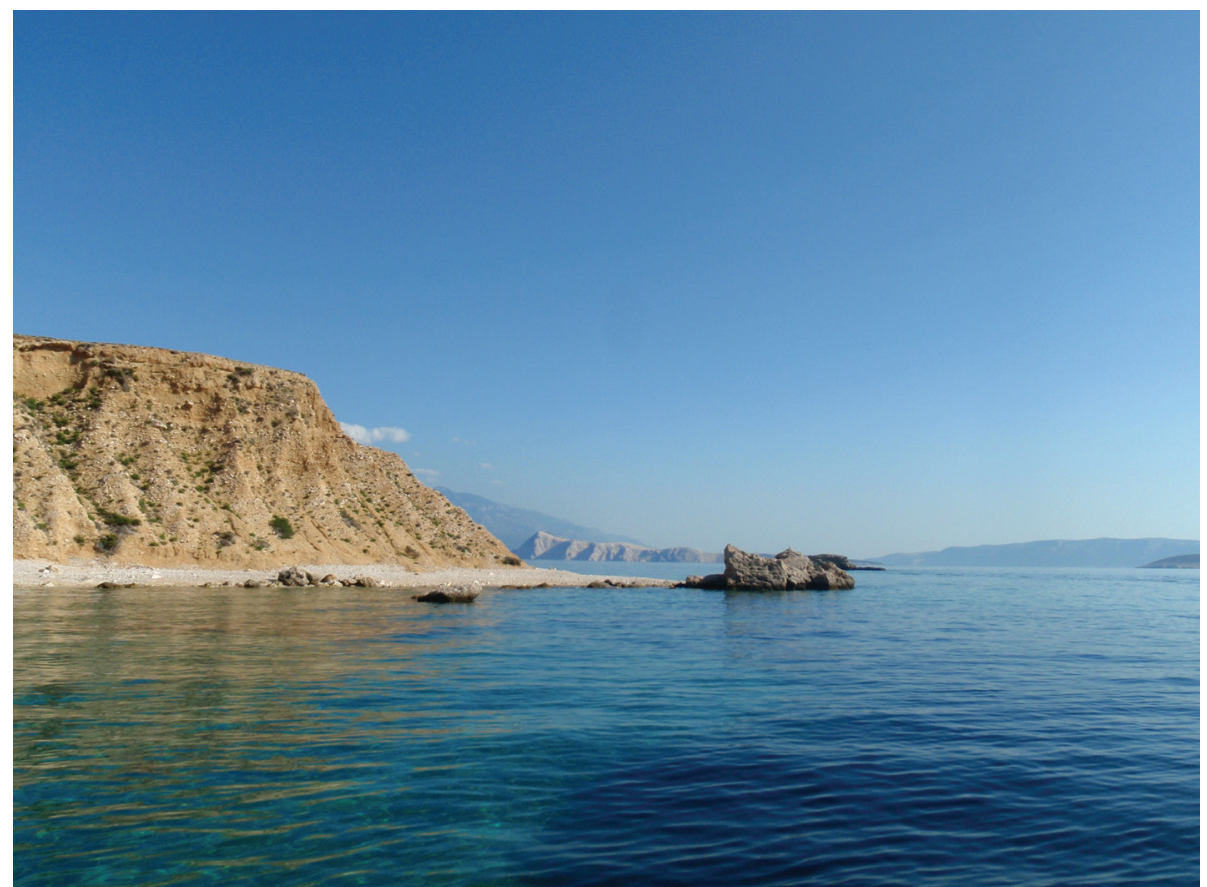

Figure 11. The recent tombolo protected by rocky blocks.

ments found at the bottom of the southeastern part of the Grgur Chanel near Šilo Cape (PIKELJ et al., 2009) probably originated from these deposits.

The conditions for forming a submerged tombolo occurred during the global sea level rise in the Holocene (LAMBECK et al., 2004; BENJAMIN et al., 2017). The relatively resistant carbonate breccia played an important role in the formation of the tombolo. These large rocky blocks provide an obstacle to waves in the shallow and flattened area. This has created conditions for forming beach sediment bodies between the Njivice Rock and Prvić Island. The top of the rock is today visible above the sea surface (Fig. 2). The sea flooded the tombolo probably during the last phase of rapid sea level rise at the beginning of the Holocene and a great proportion of the Quaternary sediments was eroded and the coastal cliff was formed. However, the traces of ancient beaches are clearly visible: better on the western side, and less so on the southeastern side (Fig. 4).

Based on the depth of the submerged tombolo of approximately $10 \mathrm{~m}$, and according to Holocene sea-level rise, it can be assumed that the fossil tombolo was formed approximately 7,000 years ago (Fig. 12). Local oceanographic conditions may have been responsible for formation of the tombolo, because the winds from southeastern directions (jugo) are more frequent and make higher waves than the winds from northwestern directions (tramuntana), driving the sediment behind the outcrop (Figs. 8, 9, 10). Sea level rise in the range of $2.0 \pm 0.9-3.4 \pm 1.1 \mathrm{~mm} / \mathrm{yr}$ has been recorded from the beginning of instrumental measurements in the Adriatic Sea (TSIMPLIS et al., 2009). According to new analyses, predicted sea level rise could be $62 \pm 14 \mathrm{~cm}$ by the end of the $21^{\text {st }}$ century (ORLIĆ \& PASARIĆ, 2013). Possible indications of accelerated sea level rise include extremely high tides recorded in the mareograph in Bakar city: $+117 \mathrm{~cm}$ above MSL from $1^{\text {st }}$ December 2008, $+122 \mathrm{~cm}$ above MSL from $1^{\text {st }}$ November 2012 and $+127 \mathrm{~cm}$ above MSL from $29^{\text {th }}$ October $2018^{3}$. This indicates that the recent tombolo is (under these given conditions) an unstable form and it could therefore be eroded and submerged in the future. These recorded extremely high tides are probably the start of a new sustained trend, which will have a negative impact on tombolo stability. Ac-

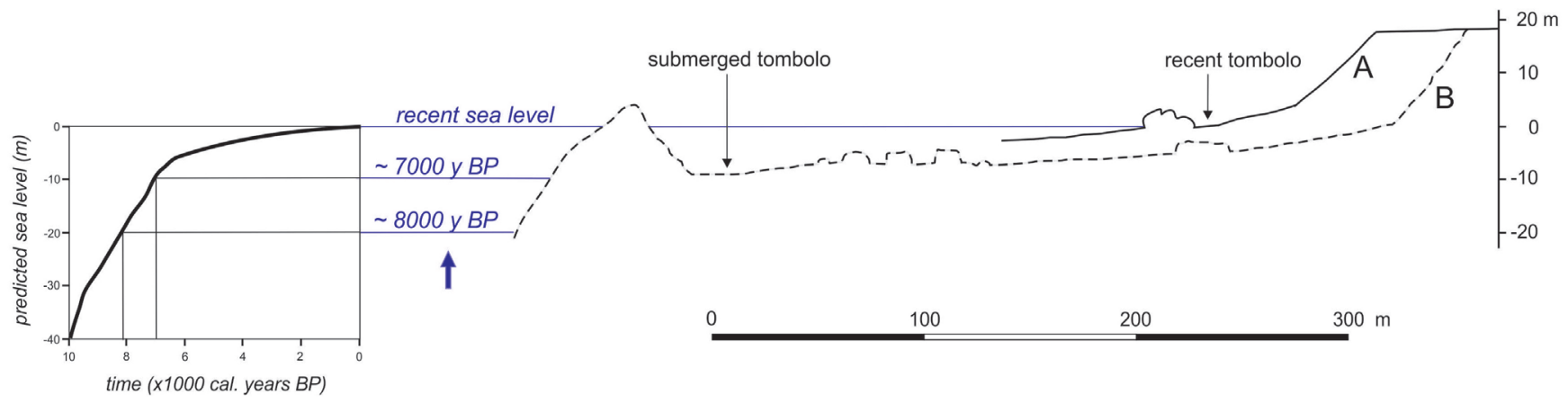

Figure 12. The position of the recent and submerged tombolos relative to Holocene sea level rise (according to LAMBECK et al., 2004). A and B are cross-sections lines (see Figs. 6, 7).

\footnotetext{
${ }^{3}$ According to data provided by Andrija Mohorovičić Geophysical Institute, Department of Geophysics, Faculty of Science, University of Zagreb
} 
cording to the expected sea-level rise and more frequent events of extremely high water levels (Acqua Alta) in the Kvarner area, coastal processes might become more intensive. This could contribute to the acceleration of marine erosion, cliff retreat and expressive changes of beach bodies including tombolos.

\section{CONCLUSIONS}

Within this research, the existence of two (recent and fossil/submerged) tombolos in neighbouring locations on Prvić Island in the northern Adriatic Sea has been reported.

There are three geomorphological factors important for the emergence of these tombolos: (1) specific geological fabric, (2) oceanographic conditions and (3) sea level change during the Holocene.

The atypical appearance of Palaeogene flysch, Quaternary clastites, and submerged subrecent potential prolluvial fans, all in an area dominated by karstified carbonates, enabled the existence of obstacles as a prerequisite for the formation of tombolos. In addition, geological specificities have enabled the source of material to feed both (recent and submerged) tombolos. Windy waves from the northwest (tramuntana) and southeast (jugo) together with generated longshore currents are responsible for coastal erosion and accumulation of sediment in the beach bodies at Cape Pipa.

Sea level rise during the Holocene allowed the emergence of two tombolos at different heights at different times. Regarding the depth of approx. $10 \mathrm{~m}$ it is supposed that the fossil tombolo could have been submerged approximately 7,000 years ago.

Two generations of tombolos co-existing at close proximity is a unique phenomenon in the Adriatic Sea, and possibly in the Mediterranean Sea.

\section{ACKNOWLEDGMENT}

This work has been supported in part by the University of Rijeka under the projects Uniri-tehnic-18-97 1232, Uniri-tehnic-18-298 6805 and GEOSEKVA (HRZZ IP-2016-06-1854).

\section{REFERENCES}

AIELlO, G., BARRA, D., DE PIPPO, T., DONADIO, C. \& PETROSINO, C. (2007): Geomorphological evolution of Phlegrean volcanic islands near Naples, southern Italy.- Zeitschrift für Geomorphologie, 51/2, 165-190. doi: 10.1127/03728854/2007/0051-0165

BENAC, Č. \& JURAČIĆ, M. (1998): Geomorphological indicators of the sea level changes during Upper Pleistocene (Wuerm) and Holocene in the Kvarner region.- Acta Geographica Croatica, 33, 27-45.

BENAC, Č., JURAČIĆ, M., MATIČEC, D., RUŽIĆ, I. \& PIKELJ, K. (2013): Fluviokarst and classical karst: Examples from the Dinarics (Krk Island, Northern Adriatic, Croatia). Geomorphology, 184, 64-73. doi: 10.1016/j.geomorph.2012.11.01

BENJAMIN, J., ROVERE, A., FONTANA, A., FURLANI, S., VACCHI, M., INGLIS, R.H., GALILI, E., ANTONIOLI, F., SIVAN, D., MIKO, S., MOURTZAS, N., FELJA, I., MEREDITH-WILLIAMS, M., GOODMAN-TCHERNOV, B., KOLAITI, E., ANZIDEI, M. \& GEHRELS, R. (2017): Late Quaternary sea-level changes and early human societies in the central and eastern Mediterranean Basin: An interdisciplinary review.- Quaternary International, 449, 29-57. doi. org/10.1016/j.quaint.2017.06.025

BOOIJ, N., RIS, R.C. \& HOLTHUIJSEN, L.H. (1999): A third-generation wave model for coastal regions, Part I: Model description and validation.- Journal of Geophysical Research, 104 (C4), 7649-7666.

CEYLAN, M.A. (2012): General Overview of the Tombolos on Turkey's Coastlines. World Applied Sciences Journal, 16/7, 907-914.

COWELL, P.J. \& THOM, B.G. (1997): Morphodynamics of coastal evolution.- In: CARTER, R.W.G. \& WOODROOFE, C.D. (eds.): Coastal evolution. Cambridge Univ. Press, Cambridge, 33-86.

DAVIES, J.L. (1980): Geographical Variation in Coastal Development. Longman, London-New York, 212 p.
DUPLANČIĆ LEDER, T., UJEVIĆ, T. \& ČALA, M. (2004): Coastline lengths and areas of islands in the Croatian part of the Adriatic Sea determined from the topographic maps at the scale of 1:25 000.- Geoadria, 9/1, 4-32. doi: 10.15291/geoadria.127

FLINN, D. (1997): The role of wave diffraction in the formation of St. Ninian's Ayre (Tombolo) in Shetland, Scotland.- Journal of Coastal Research, 13, 202-208. doi: 10.2112/JCOASTRES-D-12-00

GAMS, I., ZEREMSKI, M., MARKOVIĆ, M., LISENKO, S. \& BOGNAR, A. (1985): Uputstvo za izradu detaljne geomorfološke karte 1: 100000 [A guide to making a detailed geomorphological map 1: 100000 - in Croatian].- Komisija za geomorfološko kartiranje SFRJ, Beograd, $80 \mathrm{p}$.

GOSSEAUME, E. (1973): Le tombolo triple d'Orbetello (Toscane).- Bulletin de la Société Languedocienne de Géographie, 7, 3-11.

HANSOM, J.D. (2003): St Ninian's tombolo-- In: MAY, V.J. \& HANSOM, J.D. (eds.): Coastal Geomorphology of Great Britain. Geological Conservation Review, 28, $1-5$.

JURAČIĆ, M., BENAC, Č., PIKELJ, K. \& ILIĆ, S. (2009): Comparison of the vulnerability of limestone (karst) and siliciclastic coasts (example from the Kvarner area, NE Adriatic, Croatia).- Geomorphology, 107/1-2, 90-99. doi: 10.1016/j.geomorph.2007.05.020

KAN, H., HORI, N., KAWANA, T., KAIGARA, T. \& ICHIKAWA, K. (1997): The evolution of a Holocene fringing reef and island: reefal environmental sequence and sea level change in Tonaki Island, the central Ryukyus.- Atoll Research Bulletin, $443,1-20$.

LAMBECK, K., ANTONIOLI, F., PURCELL, A. \& SILENZI, I.S. (2004): Sea-level change along the Italian coast for the past 10,000 yr.- Quaternary Science Reviews, 24, 1567-1598. doi: 10.1016/j.quascirev.2004.02.009

MAMUŽIĆ, P., MILAN, A., KOROLIJA, B., BOROVIĆ, I. \& MAJCEN, Ž. (1969): Osnovna geološka karta SFRJ 1:100.000, list Rab L 33-114 [Basic Geological Map of SFRY 1:100.00, Rab sheet - in Croatian].- Institut za geološka istraživanja, Zagreb. Savezni geološki zavod, Beograd.

MARRINER, N., MORHANGE, C. \& MEULÉ, S. (2007): Holocene morphogenesis of Alexander the Great's isthmus at Tyre in Lebanon.- PNAS, 104/22, 9218-9223. doi.org/10.1073/pnas.0611325104

MARRINER, N., GOIRAN, J.P. \& MORHANGE, C. (2008): Alexander the Great's tombolos at Tyre and Alexandria, eastern Mediterranean.- Geomorphology, 100/(3-4), 377-400. doi: 10.1016/j.geomorph.2008.01.013

MARJANAC, LJ. (2012): Pleistocene glacial and periglacial sediments of Kvarner, northern Dalmatia and southern Velebit Mts. - evidence of Dinaric glaciation.- Unpubl. $\mathrm{PhD}$ Thesis, Faculty of Science, University of Zagreb, $278 \mathrm{p}$.

ORLIĆ, M. \& PASARIĆ, Z. (2013): Semi-empirical versus process-based sea-level projections for the twenty-first century.- Nature Climate Change, 3, 735-738. doi: 10.1038/nclimate 1877

PAVLOPOULOS, K., EVELPIDOU, N. \& VASSILOPOULOS, A. (2009): Mapping Geomorphological Environments. Springer, Dordrecht-Heidelberg-London-New York, 236 p. doi: 10.1007/978-3-642-01950-0

PENZAR, B., PENZAR, I. \& ORLIĆ, M. (2001): Vrijeme i klima hrvatskog Jadrana, Biblioteka Geographia Croatica, 16, Hrvatski hidrografski institut, Split, 258 p.

PIKELJ, K., ŽIGIĆ, V. \& JURAČIĆ, M. (2009): Origin and distribution of surface sediments in the Grgur Channel, Adriatic Sea, Croatia.- Geologia Croatica, 62/2, 95-105. doi: 10.4154/GC.2009.08

PIKELJ, K. \& JURAČIĆ, M. (2013): Eastern Adriatic Coast (EAC): Geomorphology and Coastal Vulnerability of a Karstic Coast.- Journal of Coastal Research, 29/4, 944-957. doi: 10.2112/JCOASTRES-D-12-00136.1

SANDERSON, P.G. \& ELIOT, I. (1996): Shoreline Salients, Cuspate Forelands and Tombolos on the Coast of Western Australia.- Journal of Coastal Research, 12/3, 761-773.

SCHWARTZ, M.L., GRANO, O. \& PYOKARI, M. (1989): Spits and tombolos in the southwest archipelago of Finland.- Journal of Coastal Research, 5, 443-451.

SURIĆ, M. (2009): Reconstructing sea-level changes on the Eastern Adriatic Sea (Croatia) - an overview.- Geoadria, 14/2, 181-199. doi: 10.15291/geoadria.550

TSIMPLIS, M.N., RAICICH, F., FENOGLIO-MARC, L., SHAW, A.G.P., MARCOS, M., SOMOT, S. \& BERGAMASCO, A. (2009): Recent developments in understanding sea level rise at the Adriatic coasts.- Physics and Chemistry of the Earth. Parts A/B/C, 59-71. doi: 10.1016/j.pce.2009.11.007

TORAB, M. (2016): Geomorphological \& Geoarchaeological Indicators of the Holocene Sea-Level Changes on Ras El Hekma Area, NW Coast of Egypt.- Journal of African Earth Sciences, 114, 85-95. doi: 10.1016/j.jafrearsci.2015.11.001

VU, M.T., LACROIX, Y. \& NGUYEN, V.T. (2018a): Investigating the effects of sea-level rise on morphodynamics in the western Giens tombolo, France.- IOP Conference Series: Earth and Environmental Science (EES), 167, 1-8. doi: 10.1088/1755$1315 / 167 / 1 / 012027$

VU, M.T., LACROIX, Y. \& NGUYEN, V.T. (2018b): Empirical Equilibrium Beach Profiles Along the Eastern Tombolo of Giens.- Journal of Marine Science and Application, 17/2, 241-253. doi: 10.1007/s11804-018-0027-3

WARD, S. (2004): Tombolo.- In: GOUDIE, A.S. (ed.): Encyclopedia of geomorphology. Rutledge, IAG, London-New York, 1054 p. 